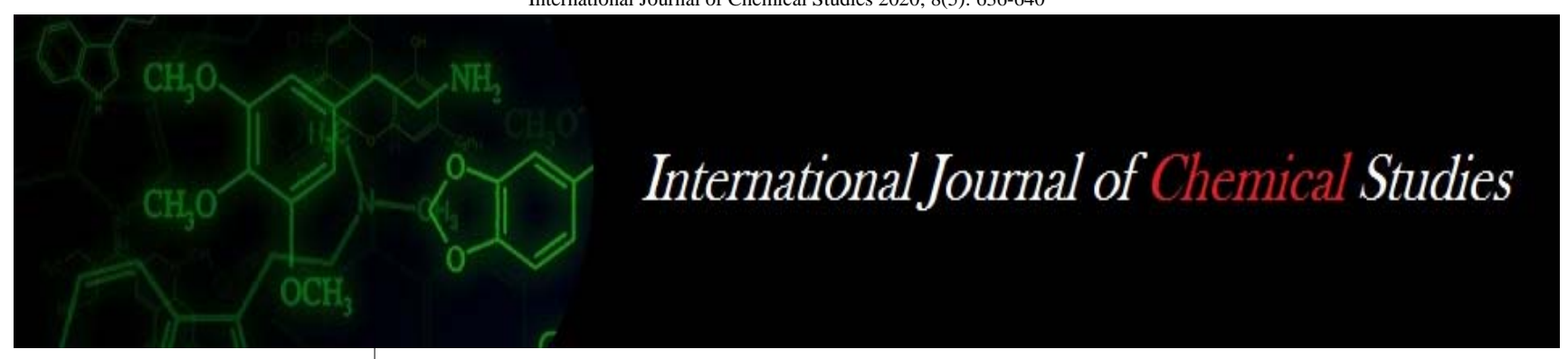

P-ISSN: 2349-8528 E-ISSN: 2321-4902 www.chemijournal.com IJCS 2020; 8(5): 636-640 (C) 2020 IJCS

Received: 16-05-2020 Accepted: 21-06-2020

BN Niranjan

Ph.D. Scholar, Department of Soil Science and Agricultural

Chemistry, College of Agriculture, UAS, GKVK, Bengaluru, Karnataka, India

\section{HC Prakasha}

Professor, Department of Soil

Science and Agricultural

Chemistry, College of

Agriculture, UAS, GKVK,

Bengaluru, Karnataka, India

\section{SK Kiran}

Ph.D. Scholar, Department of

Soil Science and Agricultural

Chemistry, College of

Agriculture, UAS, GKVK,

Bengaluru, Karnataka, India

Basavashri Yadawad M.Sc. (Agri.), Department of Soil Science and Agricultural Chemistry, College of Agriculture, UAS, GKVK, Bengaluru, Karnataka, India

Corresponding Author: BN Niranjan Ph.D. Scholar, Department of Soil Science and Agricultural Chemistry, College of Agriculture, UAS, GKVK, Bengaluru, Karnataka, India

\section{Effect of biochar on physico-chemical properties of acidic soil}

\author{
BN Niranjan, HC Prakasha, SK Kiran and Basavashri Yadawad
}

DOI: https://doi.org/10.22271/chemi.2020.v8.i5i.10373

\section{Abstract}

A field experiment was conducted at farmer's field in Byrasandra village of Shidlaghatta, Chikkaballapura to study the effect of biochar on chemical properties in acidic soil during Kharif 2017. The field trail included seven treatments with three replications. The results revealed that application of Recommended dose of fertilizers +125 per cent of biochar equivalent of carbon in FYM recorded higher primary, secondary and micronutrient status in soil and increased $\mathrm{pH}, \mathrm{EC}$, organic carbon and significantly decreased Exchangeable Al. The study clearly showed that in acidic soils, application of Recommended dose of fertilizers +125 per cent of biochar equivalent of FYM is more beneficial in reducing soil acidity and bulk density.

Keywords: acidic soil, pH, EC, exchangeable Al, biochar, FYM

\section{Introduction}

The world's population is continuously rising and the current projections indicate that the population is likely to increase from 6.9 billion people at present to 9.1 billion by 2050. As a result world food demand will surge and it is projected that food production will increase by 70 per cent in the world and 100 per cent in the developing countries. But intensive cultivation and application of ammonical fertilizers, causing soil acidity and degradation. Soil acidity is a condition where Hydrogen $\left(\mathrm{H}^{+}\right)$and aluminum $\left(\mathrm{Al}^{3+}\right)$ ion are dominance in the soil exchangeable complex causes acidity which limits crop yield Soil acidity is particularly prevalent in the humid tropics and subtropics. Out of $328 \mathrm{~m}$ ha of geographical area of India, nearly $145 \mathrm{~m}$ ha is cultivated and a rough estimate indicated that $48 \mathrm{~m}$ ha of soil is acidic in nature of which $25 \mathrm{~m}$ ha shows $\mathrm{pH}$ below 5.5, while about $23 \mathrm{~m}$ ha has $\mathrm{pH}$ between 5.6 and 6.5. Out of the $19.2 \mathrm{~m}$ ha of geographical area in Karnataka, nearly $9.6 \mathrm{~m}$ ha (50 per cent of the total area) is acidic in nature. Ananthanarayana (1996) ${ }^{[1]}$ reported that in Karnataka, acid soils are spread in the districts of Dakshina Kannada (72\%), Uttara Kannada (65\%), Kodagu (40\%), Chickmagalur (39\%), Shimoga (33\%), Hassan (20\%), Mysore (15\%), Mandya (12\%), Bangalore (10\%) and Belgaum (10\%).

In the recent years, the environmentalists and agricultural scientists have realized that continued and unbalanced use of fertilizers led to degradation of soil health there by it causes environmental pollution and affect the soil biological activity. Thus, increasing awareness is being created on the use of biochar and organic resourses to sustain the soil fertility and productivity.

Biochar is a carbon rich source, fine-grained and highly porous substance used as an amendment in acid soil. Because biochar could be attributed to high surface area that increases the cation exchange capacity (CEC) of the soil. It is alkalinity in nature and have the presence of high exchangeable bases. Yuan et al. (2011) ${ }^{[26,27]}$ revealed that alkalinity of biochar was a key factor affecting their liming potential, and the greater alkalinity of biochars led to greater reductions in soil acidity. The incorporation of biochars decreased soil exchangeable acidity and increased soil exchangeable base cations and base saturation, thus improving soil fertility. As the soil $\mathrm{pH}$ increases, the soluble and exchangeable $\mathrm{Al}^{3+}$ precipitates as insoluble hydroxyl Al-species (Ritchie 1994) ${ }^{[21]}$. Apart from the increase in soil $\mathrm{pH}$, the incorporation of biochars can release their base cations into the acidic soil which can participate in exchange reactions and replace the exchangeable $\mathrm{Al}^{3+}$ and $\mathrm{H}^{+}$on the soil surface and decrease the soil exchangeable acidity (Warnock et al., 2007, Chan et al., 2008; Yuan et al., 2011) ${ }^{[25,4,26,27] .}$ 
The thermal conversion of biomass (pyrolysis) in a low or no oxygen environment produces high carbonaceous biochar material or charcoal with unique characteristics (Gaskin et al. 2008) ${ }^{[7]}$.

The biochar has been found to have a great impact on soil fertility and increase in crop yield without causing any deleterious hazards on soil. The objective of this study was to evaluate the effect of biochar on selected chemical properties of acidic soil such as soil $\mathrm{pH}, \mathrm{EC}$, exchangeable $\mathrm{Al}$ and nutrient status.

\section{Material and methods}

The study was conducted during kharif season 2017 at farmers field in Byrasandra village of Chikkaballapura district located at Eastern Dry Zone of Karnataka. During crop growth period, a total rainfall of $358.2 \mathrm{~mm}$ was received from September to December. Maximum temperature ranged from $27.2{ }^{\circ} \mathrm{C}$ to $34.5{ }^{\circ} \mathrm{C}$ and minimum temperature ranged from $19.0{ }^{0} \mathrm{C}$ to $20.5{ }^{0} \mathrm{C}$. The experiment was laid out in a randomized complete block design (RCBD) with seven treatment combination replicated thrice. The treatments were $\mathrm{T}_{1}: \mathrm{NPK}+\mathrm{ZnSO}_{4}$ alone, $\mathrm{T}_{2}: \mathrm{NPK}+\mathrm{ZnSO}_{4}+\mathrm{FYM}(\mathrm{POP})$, $\mathrm{T}_{3}: \mathrm{NPK}+\mathrm{ZnSO}_{4}+25 \%$ of biochar equivalent of $\mathrm{FYM}, \mathrm{T}_{4}$ : $\mathrm{NPK}+\mathrm{ZnSO}_{4}+50 \%$ of biochar equivalent of FYM, T5: NPK $+\mathrm{ZnSO}_{4}+75 \%$ of biochar equivalent of FYM, $\mathrm{T}_{6}: \mathrm{NPK}+$ $\mathrm{ZnSO}_{4}+100 \%$ of biochar equivalent of $\mathrm{FYM}, \mathrm{T}_{7}: \mathrm{NPK}+$ $\mathrm{ZnSO}_{4}+125 \%$ of biochar equivalent of FYM. The recommended dose of fertilizers were applied at 100, 50, 50 and $20 \mathrm{~kg}$ of $\mathrm{N}, \mathrm{P}_{2} \mathrm{O}_{5}, \mathrm{~K}_{2} \mathrm{O}$ and $\mathrm{ZnSO}_{4}$ per hectares, respectively and farmyard manure was applied at 10 tons per hectares. The application of Biochar was based on the carbon equivalent of FYM.

The representative biochar sample was obtained from locally available wood biochar (Prosopis juliflora). The wood biochar was ground to pass through $2 \mathrm{~mm}$ sieve and analyzed for different physical and chemical parameters and results are presented in Table 1 . The initial physical and chemical properties of experimental site were analyzed and are represented in Table 2. The soil of the experimental site was acidic in soil reaction ( $\mathrm{pH}$ of 5.46) with organic carbon content of $5.30 \mathrm{~g} \mathrm{~kg}^{-1}$ and exchangeable $\left.\mathrm{Al} 1.19 \mathrm{cmol}^{+} \mathrm{p}^{+}\right) \mathrm{kg}^{-}$ 1 . The available nutrient status of soil were low in available $\mathrm{N}$ (250.84 kg ha-1), medium in available $\mathrm{P}_{2} \mathrm{O}_{5}\left(26.32 \mathrm{~kg} \mathrm{ha}^{-1}\right)$ and medium in available $\mathrm{K}_{2} \mathrm{O}$ (174.13 $\left.\mathrm{kg} \mathrm{ha}^{-1}\right)$ status.

Soil samples collected from each plot were air dried, passed through $2 \mathrm{~mm}$ sized sieve and analyzed for physical and chemical properties by adopting standard chemical analytical methods. Soil $\mathrm{pH}$ was determined by method potentiometry (Jackson, 1973) [15], Electrical conductivity (dS m${ }^{-1}$ ) was determined by method conductometry (Jackson, 1973) [15], Organic carbon $\left(\mathrm{g} \mathrm{kg}^{-1}\right.$ ) by wet oxidation method (Walkley and Black, 1934) Exchangeable $\mathrm{Al} \mathrm{(c} \mathrm{mol}\left(\mathrm{p}^{+}\right) \mathrm{kg}^{-1}$ ) was determined by the method (Yuan, 1959) [28], and Micronutrients were determined by DTPA extraction method (Lindsay and Norvell, 1978) ${ }^{[19]}$,

Statistical analysis: Experimental data obtained were subjected to statistical analysis adopting Fisher's method of analysis of variance as outlined by Gomez and Gomez (1984) [10]. The level of significance used in ' $F$ ' test was given at 5 per cent. Critical difference (CD) values are given in the Table at 5 per cent level of significance, wherever the ' $F$ ' test was found significant at 5 per cent level

\section{Results and discussion \\ Effect of biochar on physical properties of acidic soil Bulk density}

The data pertaining to effect of biochar application on bulk density of soil is presented in Table 3 . The bulk density $(1.40$ $\mathrm{Mg} \mathrm{m}^{-3}$ ) of soil was significantly recorded higher in $\mathrm{T}_{1}$ which received 100 per cent $\mathrm{NPK}+\mathrm{ZnSO}_{4}$ without the application of biochar. While significantly lower BD (1.28 $\left.\mathrm{Mg} \mathrm{m}^{-3}\right)$ was observed in the treatment $\mathrm{T}_{7}$ which received 100 per cent $\mathrm{NPK}+\mathrm{ZnSO}_{4}+125 \%$ of biochar equivalent of FYM followed by $\mathrm{T}_{6}\left(1.31 \mathrm{Mg} \mathrm{m}^{-3}\right)$ and $\mathrm{T}_{5}\left(1.35 \mathrm{Mg} \mathrm{m}^{-3}\right)$ received 100 per cent $\mathrm{NPK}+\mathrm{ZnSO}_{4}+100$ per cent of biochar equivalent of FYM and 100 per cent $\mathrm{NPK}+\mathrm{ZnSO}_{4}+75$ per cent of biochar equivalent of FYM, respectively.

Table 1: Physical and chemical characteristics of Biochar

\begin{tabular}{|c|c|}
\hline P[-Parameters & Value \\
\hline $\mathrm{pH}$ & 10.12 \\
\hline${\text { EC }\left(\mathrm{dS} \mathrm{m}^{-1}\right)}^{-1}$ & 2.92 \\
\hline Maximum water holding capacity (\%) $^{-1}$ & 62 \\
\hline Bulk density (Mg m $^{-3}$ ) & 0.48 \\
\hline Total carbon (\%) $^{(\%)}$ & 74.50 \\
\hline Nitrogen (\%) & 0.24 \\
\hline Phosphorus (\%) & 0.13 \\
\hline Potassium (\%) & 1.38 \\
\hline Calcium (\%) & 2.32 \\
\hline Magnesium (\%) & 0.46 \\
\hline Sulphur (\%) & 0.08 \\
\hline Iron (ppm) & 432.60 \\
\hline Manganese (ppm) & 514.27 \\
\hline Zinc (ppm) & 22.80 \\
\hline Copper (ppm) & 33.20 \\
\hline
\end{tabular}

Table 2: Initial physico-chemical properties of the soil of the experimental site

\begin{tabular}{|c|c|}
\hline Parameters & Value \\
\hline Sand (\%) & 61.55 \\
\hline Silt (\%) & 21.5 \\
\hline Clay (\%) & 16.8 \\
\hline Textural class & Sandy loam \\
\hline Bulk density $\left(\mathrm{g} \mathrm{cc}^{-1}\right)$ & 1.41 \\
\hline Maximum water holding capacity (\%) & 34 \\
\hline Soil pH & 5.46 \\
\hline Electrical conductivity $\left(\mathrm{dS} \mathrm{m} \mathrm{m}^{-1}\right)$ & 0.098 \\
\hline Organic carbon $\left(\mathrm{g} \mathrm{kg}^{-1}\right)$ & 5.30 \\
\hline Available $\mathrm{N}\left(\mathrm{kg} \mathrm{ha}^{-1}\right)$ & 250.84 \\
\hline Available $\mathrm{P}_{2} \mathrm{O}_{5}\left(\mathrm{~kg} \mathrm{ha}^{-1}\right)$ & 26.32 \\
\hline Available $\mathrm{K}_{2} \mathrm{O}\left(\mathrm{kg} \mathrm{ha}^{-1}\right)$ & 174.13 \\
\hline Available S (ppm) & 15.82 \\
\hline Exchangeable Ca (c mol $\left.\left(\mathrm{p}^{+}\right) \mathrm{kg}^{-1}\right)$ & 2.24 \\
\hline Exchangeable $\mathrm{Mg}\left(\mathrm{c} \mathrm{mol}\left(\mathrm{p}^{+}\right) \mathrm{kg}^{-1}\right)$ & 1.78 \\
\hline DTPA Zn (ppm) & 1.50 \\
\hline DTPA Fe (ppm) & 12.18 \\
\hline DTPA Cu (ppm) & 0.84 \\
\hline DTPA Mn (ppm) & 30.94 \\
\hline Available B (ppm) & 0.38 \\
\hline Exchangeable $\mathrm{Al}\left(\mathrm{c}\right.$ mol $\left.\left(\mathrm{p}^{+}\right) \mathrm{kg}^{-1}\right)$ & 1.19 \\
\hline
\end{tabular}

\section{Maximum water holding capacity}

The data pertaining to effect of varied levels of biochar application on maximum water holding capacity of soil is presented in Table 3. The application of 100 per cent NPK + $\mathrm{ZnSO}_{4}+125$ per cent of biochar equivalent of FYM recorded 
significantly maximum water holding capacity (42.23\%) in soil followed by application of 100 per cent NPK $+\mathrm{ZnSO}_{4}+$ 100 per cent of biochar equivalent of FYM (40.50 \%). The lower water holding capacity of soil $(34.07 \%)$ was observed in the treatment that received 100 per cent $\mathrm{NPK}+\mathrm{ZnSO}_{4}$ (control).

The physical properties of soil viz., bulk density and maximum water holding capacity were significantly influenced by biochar application. Among the different treatments, the treatment which received 100 per cent NPK + $\mathrm{ZnSO}_{4}+125$ per cent of biochar equivalent of FYM recorded lower bulk density and maximum water holding capacity over the rest of the treatments. This could be attributed to total carbon content in the biochar which acts as cementing materials in forming stable soil aggregates. It has been reported that the porous structure of biochar can influence its impact on soil water holding capacity and adsorption capacity (Ogawa and okiomori 2010) ${ }^{[20]}$. Similar results were reported by Emmanuel et al. (2010) [6] and Gundale and DeLuca

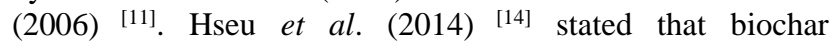
application reduced the bulk density by 12 to 25 per cent and the penetration resistance by 57 to 92 per cent after incubation, of compared with the control. Besides, porosity and aggregate size increased by 16 to 22 per cent and by 0.59 to $0.94 \mathrm{~mm}$, respectively.

Table 3: Effect of biochar application on bulk density (BD) and maximum water holding capacity (MWHC) of post harvested soil in finger millet under the field condition

\begin{tabular}{|c|c|c|}
\hline Treatment details & $\mathrm{BD}\left(\mathrm{g} \mathrm{cc}^{-1}\right)$ & MWHC (\%) \\
\hline $\mathrm{T}_{1}: \mathrm{NPK}+\mathrm{ZnSO}_{4}$ alone & 1.40 & 34.07 \\
\hline $\mathrm{T}_{2}: \mathrm{NPK}+\mathrm{ZnSO}_{4}+\mathrm{FYM}(\mathrm{POP})$ & 1.33 & 38.41 \\
\hline $\mathrm{T}_{3}: \mathrm{NPK}+\mathrm{ZnSO}_{4}+25 \%$ of biochar equivalent of FYM & 1.39 & 35.62 \\
\hline $\mathrm{T}_{4}: \mathrm{NPK}+\mathrm{ZnSO}_{4}+50 \%$ of biochar equivalent of FYM & 1.37 & 35.12 \\
\hline $\mathrm{T}_{5}: \mathrm{NPK}+\mathrm{ZnSO}_{4}+75 \%$ of biochar equivalent of FYM & 1.35 & 36.75 \\
\hline $\mathrm{T}_{6}: \mathrm{NPK}+\mathrm{ZnSO}_{4}+100 \%$ of biochar equivalent of FYM & 1.31 & 40.50 \\
\hline $\mathrm{T}_{7}: \mathrm{NPK}+\mathrm{ZnSO}_{4}+125 \%$ of biochar equivalent of FYM & 1.28 & 42.23 \\
\hline S.EM \pm & 0.01 & 0.24 \\
\hline CD@ (5\%) & 0.02 & 0.75 \\
\hline
\end{tabular}

\section{Effect of biochar on chemical parameters of acidic soil Soil pH}

The data in Table 4 revealed that there was significant difference among different treatments with respect to soil $\mathrm{pH}$ after harvest of finger millet crop. The soil $\mathrm{pH}$ (6.44) was significantly increased by application of 100 per cent RDF + $\mathrm{ZnSO}_{4}+125$ per cent of biochar equivalent of FYM as compared to application of 100 per cent $\mathrm{NPK}+\mathrm{ZnSO}_{4}+$ FYM. The lowest soil $\mathrm{pH}$ was recorded in the plot which received chemical fertilizers alone in treatment $T_{2}$.

The increase in $\mathrm{pH}$ of soil over control is due to application of biochar could be attributed to high surface area that increases the cation exchange capacity (CEC) of the soil. It is also due to alkalinity nature of biochar and the presence of high exchangeable bases. Similar results were noticed by Chintala et al. (2014) ${ }^{[5]}$, Anteneh et al. (2014) ${ }^{[2]}$, Hass et al. (2012) ${ }^{[13]}$ and Yuan et al. (2011) ${ }^{[26,27]}$.

\section{Electrical conductivity (EC)}

The data on electrical conductivity (EC) in Table 4 showed that there was significant difference among the different treatments with respect to soil EC after harvest of finger millet. The EC $\left(0.19 \mathrm{dS} \mathrm{m} \mathrm{m}^{-1}\right)$ was significantly higher in treatment imposed of 100 per cent $\mathrm{NPK}+\mathrm{ZnSO}_{4}+125$ per cent of biochar equivalent of FYM as compared to control which received 100 percent $\mathrm{NPK}+\mathrm{ZnSO}_{4}$ alone $\left(0.10 \mathrm{dS} \mathrm{m}^{-}\right.$ $\left.{ }^{1}\right)$. Further, there was a gradual increase in EC with increasing levels of biochar. It might be due to the salt concentration and exchangeable cations in wood biochar which can increase the EC of soil. Significant increase in EC with varied levels of biochar application was also reported by Chintala et al. (2014) ${ }^{[5]}$, Glaser et al. (2000) ${ }^{[8]}$, Gundale and De luca (2007) and Chan et al. (2008) ${ }^{[4]}$.

\section{Soil organic carbon}

The organic carbon content of soil after harvest of finger millet ranged from 5.40 to $6.40 \mathrm{~g} \mathrm{~kg}^{-1}$ (Table 4). Numerically higher organic carbon (6.40 $\mathrm{g} \mathrm{kg}^{-1}$ ) was recorded in the plot which received 100 per cent NPK $+\mathrm{ZnSO}_{4}+125$ per cent of biochar equivalent of FYM as compared to plot which received 100 per cent $\mathrm{NPK}+\mathrm{ZnSO}_{4}+\mathrm{FYM}$ (5.80 g kg-1). The lower value was recorded in plot which received only 100 per cent $\mathrm{NPK}+\mathrm{ZnSO}_{4}$ alone $\left(5.40 \mathrm{~g} \mathrm{~kg}^{-1}\right)$.

Application of biochar along with chemical fertilizers increased the organic carbon content in soil as compared to application of chemical fertilizers alone. It may be due to rich source of carbon which contributed higher carbon content in the soil. Similar findings of high organic carbon in soils with the application of biochar also reported by Lehmann (2007b) ${ }^{[17]}$ and Solomon et al. (2007), Hass et al. (2012) ${ }^{[13]}$, Anteneh et al. (2014) ${ }^{[2]}$ and Warnock et al. (2007) ${ }^{[25]}$.

Table 4: Effect of biochar application on pH, EC and organic carbon status of post harvested soil in finger millet under the field condition

\begin{tabular}{|c|c|c|c|c|}
\hline Treatment details & pH & EC $\left(d_{S} ~ m^{-1}\right)$ & OC $\left(\mathrm{g} \mathrm{kg}^{-1}\right)$ & Exchangeable Al (cmol (p+) kg-1) \\
\hline $\mathrm{T}_{1}: \mathrm{NPK}+\mathrm{ZnSO}_{4}$ alone & 5.47 & 0.10 & 5.40 & 1.20 \\
\hline $\mathrm{T}_{2}: \mathrm{NPK}+\mathrm{ZnSO}_{4}+\mathrm{FYM}(\mathrm{POP})$ & 5.33 & 0.13 & 5.80 & 1.16 \\
\hline $\mathrm{T}_{3}: \mathrm{NPK}+\mathrm{ZnSO}_{4}+25 \%$ of biochar equivalent of FYM & 5.57 & 0.11 & 5.50 & 1.10 \\
\hline $\mathrm{T}_{4}: \mathrm{NPK}+\mathrm{ZnSO}_{4}+50 \%$ of biochar equivalent of FYM & 5.69 & 0.14 & 5.67 & 1.09 \\
\hline $\mathrm{T}_{5}: \mathrm{NPK}+\mathrm{ZnSO}_{4}+75 \%$ of biochar equivalent of FYM & 6.12 & 0.15 & 5.97 & 1.00 \\
\hline $\mathrm{T}_{6}: \mathrm{NPK}+\mathrm{ZnSO}_{4}+100 \%$ of biochar equivalent of FYM & 6.36 & 0.18 & 6.20 & 0.98 \\
\hline $\mathrm{T}_{7}: \mathrm{NPK}+\mathrm{ZnSO}_{4}+125 \%$ of biochar equivalent of FYM & 6.44 & 0.19 & 6.40 & 0.96 \\
\hline S.EM \pm & 0.08 & 0.01 & 0.06 & 0.01 \\
\hline CD@ (5\%) & 0.26 & 0.02 & 0.19 & 0.02 \\
\hline
\end{tabular}




\section{Exchangeable aluminum}

The results indicated in table 4 showed that there was significant decrease in exchangeable aluminum in biochar plots compared. Among the treatments, the lowest exchangeable aluminum of $0.96 \mathrm{c} \mathrm{mol}\left(\mathrm{p}^{+}\right) \mathrm{kg}^{-1}$ was recorded in the plot treated with 100 per cent recommended inorganic fertilizers $+\mathrm{ZnSO}_{4}+125 \%$ of biochar equivalent of FYM. It may be due to the contribution of exchangeable basic cations of soil which improved the base saturation and thus improved soil acidity. Yuan and Xu. (2011) ${ }^{[26,27]}$ revealed that greater alkalinity of biochar led to greater reductions in soil acidity and aluminum toxicity.

\section{DTPA extractable iron}

The iron content of post harvest soil did not show any significant difference due to different levels of biochar application. However, the numerically lower value of Fe (7.91 mg kg-1) was observed in $\mathrm{T}_{7}$ received 100 per cent NPK + $\mathrm{ZnSO}_{4}+125$ per cent of biochar equivalent of FYM, followed by $\mathrm{T}_{5}\left(8.06 \mathrm{mg} \mathrm{ka}^{-1}\right)$ and $\mathrm{T}_{6}\left(8.04 \mathrm{mg} \mathrm{ka}^{-1}\right)$ received 100 per cent $\mathrm{NPK}+\mathrm{ZnSO}_{4}+75$ per cent of biochar equivalent of FYM and 100 per cent $\mathrm{NPK}+\mathrm{ZnSO}_{4}+100$ per cent of biochar equivalent of FYM. The highest value of Fe
(12.65 mg kg-1) was found in control which received 100 per cent of $\mathrm{NPK}+\mathrm{ZnSO}_{4}$ alone $\left(\mathrm{T}_{1}\right)$.

\section{DTPA extractable manganese}

The manganese content of post harvest soil did not differ significantly due to application of varied levels of biochar (Table 5). The higher value of Mn (32.02 mg kg-1) was found in treatment $\mathrm{T}_{2}$, where 100 per cent $\mathrm{NPK}+\mathrm{ZnSO}_{4}+\mathrm{FYM}$ (POP) was applied followed by $\mathrm{T}_{1}\left(30.69 \mathrm{mg} \mathrm{kg}^{-1}\right.$ ) where 100 per cent $\mathrm{NPK}+\mathrm{ZnSO}_{4}$ was applied without application of biochar. The lower manganese content $\left(21.06 \mathrm{mg} \mathrm{kg}^{-1}\right)$ was noticed in treatment $\left(\mathrm{T}_{7}\right)$ which received 100 per cent of NPK $+\mathrm{ZnSO}_{4}+125$ per cent of biochar equivalent of FYM followed by $\mathrm{T}_{6}\left(30.69 \mathrm{mg} \mathrm{kg}^{-1}\right.$ ) received 100 per cent NPK + $\mathrm{ZnSO}_{4}+100$ per cent of biochar equivalent of FYM.

Application of wood biochar reduced $\mathrm{Fe}$ and $\mathrm{Mn}$ content in soil which might be due to the adsorption and possible immobilization. As $\mathrm{pH}$ of soil and micronutrient availability is negatively correlated, immobilization of micronutrient occurs in soil. The decreased trend of metal content with different rate of biochar application was likely a function of increase in total amount of active sites (Kimetu and Lehmann $(2010)^{[16]}$.

Table 5: Effect of biochar application DTPA extractable Iron and Manganese status of soil after the harvest

\begin{tabular}{|c|c|c|c|c|}
\hline Treatment details & Fe $\left(\mathrm{mg} \mathrm{kg}^{-1}\right)$ & Mn (mg kg $\left.{ }^{-1}\right)$ & $\mathrm{Zn}\left(\mathrm{mg} \mathrm{kg}^{-1}\right)$ & $\mathrm{Cu}\left(\mathrm{mg} \mathrm{kg}^{-1}\right)$ \\
\hline $\mathrm{T}_{1}: \mathrm{NPK}+\mathrm{ZnSO}_{4}$ alone & 12.65 & 30.69 & 1.52 & 0.89 \\
\hline $\mathrm{T}_{2}: \mathrm{NPK}+\mathrm{ZnSO}_{4}+\mathrm{FYM}(\mathrm{POP})$ & 11.44 & 32.02 & 1.58 & 0.83 \\
\hline $\mathrm{T}_{3}: \mathrm{NPK}+\mathrm{ZnSO}_{4}+25 \%$ of biochar equivalent of FYM & 10.13 & 28.96 & 1.52 & 0.90 \\
\hline $\mathrm{T}_{4}: \mathrm{NPK}+\mathrm{ZnSO}_{4}+50 \%$ of biochar equivalent of FYM & 9.13 & 27.65 & 1.55 & 0.88 \\
\hline $\mathrm{T}_{5}: \mathrm{NPK}+\mathrm{ZnSO}_{4}+75 \%$ of biochar equivalent of FYM & 8.06 & 22.03 & 1.55 & 0.85 \\
\hline $\mathrm{T}_{6}: \mathrm{NPK}+\mathrm{ZnSO}_{4}+100 \%$ of biochar equivalent of FYM & 8.04 & 21.45 & 1.59 & 0.82 \\
\hline $\mathrm{T}_{7}: \mathrm{NPK}+\mathrm{ZnSO}_{4}+125 \%$ of biochar equivalent of FYM & 7.91 & 21.06 & 1.61 & 0.79 \\
\hline S.EM \pm & 0.15 & 0.38 & 0.01 & 0.01 \\
\hline CD@ (5\%) & 0.46 & 1.16 & 0.02 & 0.02 \\
\hline
\end{tabular}

\section{DTPA extractable zinc}

The DTPA extractable zinc content was found to be significantly varying between the treatments in soil due to the application of different levels of biochar (Table 5). Significantly higher value of available zinc was recorded in $\mathrm{T}_{7}\left(1.61 \mathrm{mg} \mathrm{kg}^{-1}\right)$ which received 100 per cent $\mathrm{NPK}+\mathrm{ZnSO}_{4}$ +125 per cent of biochar equivalent of FYM and found on par with $\mathrm{T}_{6}\left(1.59 \mathrm{mg} \mathrm{kg}^{-1}\right)$ received 100 per cent NPK + $\mathrm{ZnSO}_{4}+100$ per cent of biochar equivalent of FYM. The lower value was recorded in $\mathrm{T}_{1}\left(1.52 \mathrm{mg} \mathrm{kg}^{-1}\right)$ which received 100 percent $\mathrm{NPK}+\mathrm{ZnSO}_{4}$ alone.

An increase in $\mathrm{Zn}$ content in the soil with biochar application. This may be due to water holding capacity of biochar which enhanced mineralization of zinc from organic matter and the release of $\mathrm{Zn}$ during decomposition of organic manures and also due to the application of zinc sulphate as a source of zinc. Sharma and Dixit, (1987) ${ }^{[22]}$ also opined that Increase in the content of zinc might be due to higher availability of the plant nutrients from the soil nutrient reservoir and additional quantity of nutrients supplied through farm yard manure.

\section{DTPA extractable copper}

The DTPA extractable copper content was found to be significantly varying between the treatments in soil due to the application of varied levels of biochar (Table 5). Significantly higher value of available copper was recorded in $\mathrm{T}_{7}(0.89 \mathrm{mg}$ $\mathrm{kg}^{-1}$ ) received 100 per cent $\mathrm{NPK}+\mathrm{ZnSO}_{4}+125$ per cent of biochar equivalent of FYM and was on par with $\mathrm{T}_{6}(0.88 \mathrm{mg}$ $\mathrm{kg}^{-1}$ ) received 100 per cent $\mathrm{NPK}+\mathrm{ZnSO}_{4}+100$ per cent of biochar equivalent of FYM. The lower value of copper was recorded in $\mathrm{T}_{1}\left(0.79 \mathrm{mg} \mathrm{kg}{ }^{-1}\right)$ which received $\mathrm{NPK}+\mathrm{ZnSO}_{4}$ alone.

A significant increase in copper content of soil by application of biochar could increase the soluble organic carbon; thereby resulting in the mobilization of $\mathrm{Cu}$. $\mathrm{Cu}$ is strongly chelated by organic carbon and is less subjected to adsorption process. Beesley and Marmiroli (2011) ${ }^{[3]}$ also reported dependence of $\mathrm{Cu}$ content on soluble $\mathrm{C}$ and $\mathrm{pH}$ of the soil.

\section{Conclusion}

Application of 100 per cent NPK $+\mathrm{ZnSO}_{4}+125$ per cent of biochar equivalent of FYM significantly decreased the bulk density and increased water holding capacity of soil and also increased the nutrient status in acidic soil. Application of biochar significantly decreased soil acidity and improved $\mathrm{pH}$, EC and soil organic carbon content of the soil.

\section{References}

1. Ananthanarayana R. Studies on lime requirement of acid soils of south canara district, Mysore, M.Sc. Thesis. UAS, Bengaluru, 1996.

2. Anteneh A, Yitaferu B, Yihenew GS, Amar T. The role of biochar on acid soil reclamation and yield of teff (Eragrostis tef [zucc] trotter) in northwestern Ethiopia. Ethiopia J Agric. Sci. 2014; 6(1):126-138.

3. Beesley L, Marmiroli M. The immobilisation and retention of soluble arsenic, copper, cadmium and zinc by biochar. Environ. Pollution. 2011; 159:474-480. 
4. Chan KY, Van Zwieten L, Meszaros IA, Downie C, Joseph S. Using poultry litter biochar as soil amendments. Australian J Soil Res. 2008; 46: 437-444.

5. Chintala R, Javier M, Thomas ES, Douglas DM. Effect of biochar on chemical properties of acidic soil. Archeive Agron. Soil Sci. 2014; 60(3):393-404.

6. Emmanuel D, Anne V, Steve R, Sarana S. Biochar from saw dust, maize stover and charcoal: Impact on water holding capacity (WHC) of three soil from Ghana. In: $19^{\text {th }}$ world congress of soil science, soil solutions for a changing world 1-6 August 2010, Brisbane, Australia, 2010.

7. Gaskin JW, Steiner C, Harris K, Das KC, Bibens B. Effect of low-temperature pyrolysis conditions on biochar for agricultural use. Trans American Soc. Agric. Biol. Eng. 2008; 51:2061-2069.

8. Glaser B, Balashov E, Haumaier L, Guggenberger G, Zech W. Black carbon in density fractions of anthropogenic soils of the Brazilian Amazon region. Org. Geochem. 2000; 31:669-678.

9. Glaser B, Lehmann J, Zech W. Ameliorating physical and chemical properties of highly weathered soils in the tropics with charcoal - A review. Biol. Fertil. Soils. 2002; 35:219-230.

10. Gomez KA, Gomez AA. Statistical Procedures for Agric. Res. $2^{\text {nd }}$ Ed. John Wiley \& Sons, New York, 1984.

11. Gundale MJ, Deluca TH. Temperature and substrate influence the chemical properties of charcoal in the ponderosa pine /Douglas-fir ecosystem, Forest Ecology and Management. 2006; 231:86-93.

12. Gundale MJ, Deluca TH. Temperature and substrate influence the chemical properties of charcoal in the ponderosa pine /Douglas-fir ecosystem, Forest Ecology and Management. 2006; 231:86-93.

13. Hass A, Javier MG, Isabel ML, Harry WG, Jonathan JH, Douglas GB. Chicken manure biochar as liming and nutrient source for acid appalachian soil. J Environ. Qual. 2012; 41(4):1096-1106.

14. Hseu ZY, Zeng SH, Chein WH, Liuo RC. Impacts of Biochar on Physical Properties and Erosion Potential of a Mudstone Slopeland Soil. Sci. World J. 2014; 10:602197.

15. Jackson ML. Soil chemical analysis. Prentice Hall of India, New Delhi, 1973, 1-485.

16. Kimetu JM, Lehmann J. Stability and stabilization of biochar and green manure in soil with different organic carbon contents, Australian J Soil Res. 2010; 48:577-585.

17. Lehmann J. Bio-energy in the black. Frontiers. Ecol. Environ. 2007b; 5:381-389.

18. Lehmann J, Gaunt J, Rondon M. Bio-char sequestration in terrestrial ecosystems: A review. Mitig. Adapt. Strat. Gl. Chn. 2006; 11:403-427.

19. Lindsay WL, Norwell WA. Development of DTPA soil test for zinc, iron, manganese and copper. Soil Sci. Soc. Am. J. 1978; 42:421-428.

20. Ogawa M, Okimori Y. Pioneering works in biochar research, Japan, 2010, 88.

21. Ritchie GSP. Role of dissolution and precipitation of minerals in controlling soluble aluminum in acid soils. Adv. Agron. 1994; 53:47-83.

22. Sharma RA, Dixit BK. Effect of nutrient application on rainfed soybean. J Indian Soc. Soil Sci. 1987; 35:452455.

23. Solaiman ZM, Blackwell P, Abbott LK. Direct and residual effect of biochar application on mycorrhizal root colonisation, growth and nutrition of wheat. Australian J Soil Res. 2010; 48:546-554.

24. Walkley AJ, Black IA. An examination of wet acid method for determining soil organic matter and proposed modification of chromic acid titration method. J Soil Sci. 1934; 37:29-38.

25. Warnock DD, Lehmann J, Kuyper TW, Rillig MC. Mycorrhizal responses to biochar in soil-concepts and mechanisms. Plant and Soil. 2007; 300:9-20.

26. Yuan JH, XU RK. The amelioration effects of low temperature biochar generated from nine crop residues on an acidic Ultisol, Soil Use Manage. 2011; 27:110-115.

27. Yuan JH, XU RK, Zhang $H$. The forms of alkalis in the biochar produced from crop residues at different temperatures. Bioresour. Tech. 2011; 102:3488-3497.

28. Yuan TL. Determination of exchangeable hydrogen in soils by titration method, 1959 . 